\title{
Once there were so many: Animals as Ecological Baselines
}

\author{
Yolanda F. Wiersma (corresponding author) \\ Department of Biology \\ Memorial University of Newfoundland \\ St. John's, NL \\ Canada \\ ywiersma@mun.ca \\ tel: 709-864-7499 \\ John Sandlos \\ Department of History \\ Memorial University of Newfoundland \\ St. John's, NL \\ Canada \\ A1C 5S7 \\ jsandlos@mun.ca \\ tel: 709-864-2429
}




\title{
Once there were so many: Animals as Ecological Baselines Yolanda F. Wiersma and John Sandlos
}

\begin{abstract}
The observations of naturalists and explorers have been used as historical sources for determining baseline wildlife conditions from the earliest practice of modern ecology. These sources are rarely critically analyzed, however, and are often incorporated into contemporary scientific literature advocating the conservation and restoration of wildlife. This paper argues that combining approaches from environmental history and recent ecological research will allow for the interrogation of original sources and the application of scientific concepts that questions the assumptions underlying historical baselines.
\end{abstract}

Peter Matthiessen's Wildlife in America was one of the first popular books to provide a comprehensive account of the staggering population declines of North American fauna since the arrival of Europeans. Drawing on the field notes and papers of natural historians, Matthiessen invokes images of pre-contact North American wildlife abundance and subsequent declines as a prelude to his call for restoration of the most critically endangered species. Similarly, more recent proponents of large-scale wildlife restoration programs almost inevitably invoke past images of pre-contact wildlife superabundance to justify their initiatives. Where once large animals numbered in the millions, they suggest, now only thousands or even hundreds of individuals have survived the cumulative impacts of European settlement. Thus, historical wildlife population estimates are used to justify ambitious wildlife restoration projects, since they provide a baseline against which to measure the destruction of nature and loss of biodiversity at human hands. ${ }^{1}$

But where do the baseline numbers for pre-contact fauna come from? Typically, the early twentieth-century naturalists and conservationists who first calculated historical wildlife populations relied on rudimentary accounts of earlier explorers, geologists and surveyors. Using these visual accounts of bison, elk, and antelope (or, in the absence of these, using contemporaneous data from the same region on the density of domestic livestock) early naturalists then extrapolated this number over an estimated historical range. Ernest Thompson Seton adopted this technique throughout his influential multivolume 1927 study, The Lives of Game Animals. To calculate pre-contact bison numbers, for example, Seton used data on horse and cattle densities to produce a figure of sixty-five million animals. He then refined this number using the visual herd estimates of early observers, extrapolating these numbers across the total historical bison range in North America to produce a "safe estimate" of sixty million animals. Using similar methods, Seton painted a fantastic portrait of bygone North America teeming with wildlife: forty-five million antelope, forty million white tailed deer, ten million 
mule deer, ten million elk, two million bighorn sheep, one million moose, and one million wolves, all in addition to the unimaginable numbers of bison. ${ }^{2}$

The uncritical adoption of such speculative historical population baselines can produce unrealistic goals within contemporary wildlife restoration projects. In the case of the wood bison subspecies in northern Canada, for instance, a pre-contact estimate of 168,000 animals is often cited as justification for restoring seed populations throughout their estimated historical range. This number first appeared in a report that the Canadian government biologist J. Dewey Soper issued in 1941. As with Seton, Soper arrived at this figure by citing several explorers' accounts of "very plentiful" herds in the Slave and Peace River ranges and extrapolating current estimates of the bison population in Wood Buffalo National Park across an assumed historical range. Although the Canadian government's current recovery plan does not specify an absolute return to 168,000 wood bison as a primary goal, this number is often invoked as justification for stocking the species throughout all areas within its presumed historical range. ${ }^{3}$ This approach to wood bison recovery has proceeded without asking whether the sightings of "very abundant" herds were spread evenly throughout the historic wood bison range, or whether explorers travelling along the Peace River were not seeing plains bison at the edge of their range. Without such background information, can we be certain that the wood bison population prior to European contact consisted of more than a few thousand animals clinging to a sparse existence at the far edge of suitable habitat on this continent?

Despite their shortcomings, the speculative population estimates of early wildlife scientists continue to be incorporated in some peer-reviewed scientific literature and remain influential as credible baseline numbers. It is remarkable in particular how Seton's population guesswork on species such as bison, bighorn sheep, elk, and wolves has been transmitted from the older literature to very recent scientific papers outlining local restoration projects for these species. Even simple errors, such as the gradual adoption of the wrong measurement units for the baseline prairie dog rangeone hundred hectares rather than the correct figure of one hundred acres-can work their way from publication to publication and influence restoration initiations. At the very least, it is clear that some contemporary observers derive their baseline figures without a critical examination of original sources, transmitting extremely speculative population figures from one publication to the next. ${ }^{4}$

With a disciplinary training devoted to the critical examination of historical sources, much more could be done to integrate environmental history perspectives with contemporary attempts to re-wild portions of North America. But the deficiencies in historical data sets should only be a starting point for this discussion. Taken to its logical extreme, such critical analysis can leave us with no basis on which to determine historical patterns of wildlife distribution and abundance. Indeed, questions about baseline population or range size are not unanswerable; historians have much to learn from emerging ideas and techniques that contemporary ecologists have used to assess historical wildlife populations and habitats.

Many of the sources ecologists use to assess historical wildlife range and abundance are familiar to historians: museum collections, archival material, land survey records, and oral history. In one study of the Florida grouper, for example, scientists used newspaper accounts and archival photographs detailing catch totals and the size 
of individual fish to estimate historical population fluctuations. ${ }^{5}$ Ecologists have also assembled historical population estimates using sources and methods that are less well known to traditional historians, such as herbarium records, genetic analyses, sediment cores, zooarchaelogical records, and tree ring records. ${ }^{6}$ On a more abstract level, some ecologists have argued that remnant landscapes retaining a close resemblance to conditions in specific historical periods (most notably protected areas) may serve as a source of historical ecological data, a technique known as space-for-time-substitutions. ${ }^{7}$

None of these sources and analytical techniques provides an absolutely precise window on historical wildlife populations at a particular moment of time. Indeed, most ecologists readily acknowledge that ecological systems are not static: historical management interventions may have so profoundly altered conditions even in protected areas, or animal populations may have fluctuated so dramatically over time, that they must be analyzed within a concept known as the historical range of variability. Some techniques, such as tree-ring and sediment core analyses, explicitly measure some of the variability in species abundance and ecological conditions through time. In other cases where data are lacking or suspect, scientists must use modeling techniques to determine the historical range of variability. Often this is done by back-casting, a mathematical modeling technique that uses current data on demographic rates (survival, reproduction) and population densities in different habitat types to estimate historical population sizes. As Alagona (this issue) suggests, the fundamental link between habitat change and critically engendered wildlife has been recognized for some time. Thus, ecologists have often used current and historical landscape data (from satellite images, air photos and maps) and land change data (which can be complemented by archival records that document land use) to model historical land cover and habitat types. These data can then be used to estimate historical populations of species based on contemporary densities in different habitat types. ${ }^{8}$

Obviously, these techniques will always retain a degree of uncertainty. Most importantly, variations in the model inputs (i.e., which values of reproduction or survival from current populations are used) can affect final population estimates. In addition, while contemporary ecologists use more robust data sets than did Seton, they still face the basic methodological problem of estimating historical wildlife populations based on contemporary conditions that may be considerably altered. To deal with this uncertainty, ecologists often conduct a sensitivity analysis, simulating different levels of inter-annual variation in survival and reproduction through time and seeing how much the baseline population estimates vary. This method explicitly rejects the idea of singular historical population estimates, instead modeling the historical range of variability in a manner that gives scientists a probable set of values for baseline populations. ${ }^{9}$

Ecologists have also evaluated the problem of locating a baseline population at a particular moment in time. As with environmental historians, many ecologists have questioned simplistic assumptions that baseline wildlife populations in North America are inherently tied to the pre-contact period. Studies of upland birds in New England suggested, for example, that populations increased from pre-European levels coincident with agricultural expansion. Major declines in upland bird populations only began in the twentieth century after reforestation that followed the abandonment of agricultural land reclaimed suitable meadow habitats. A more recent study modeled the effects of culling bison in enclosed reserves to mimic historical levels of predation by wolves and 
indigenous hunters in an effort to keep bison at simulated baseline densities. The authors concluded that the North America bison population was probably closest to baseline conditions prior to widespread Native American use of horses in the seventeenth century rather than the more commonly cited period of westward expansion in the nineteenth century. ${ }^{10}$

Clearly, locating a population baseline at a particular moment in time presents an immense methodological challenge. As Barrow argues elsewhere in this issue, the fluid nature of animal populations might prompt some to question whether it is even possible to quantify a baseline animal population within a specific time period. But historians and ecologists have largely abandoned the concept of static and singular baseline numbers for pre-contact wildlife, using an array of methods that can quantify historical ranges and fluctuations in animal populations. Working together, historians can lead scientists to new sources of archival material and interpret historical data within broader histories of regional environmental change while ecologists can contribute to historical knowledge though applied analytical techniques that may verify or serve as a powerful corrective to assumptions about wildlife populations in published and archival sources. Both forms of knowledge are essential in the policy realm, providing a more nuanced analysis of historical wildlife population estimates that currently guide many wildlife and habitat restoration programs.

\section{Acknowledgements}

Thanks to Peter Alagona for the invitation to participate in this forum and to fellow forum participants for insightful comments. Thanks also to Nancy Langston and two anonymous reviewers for helpful feedback on an earlier version of the manuscript.

\section{Biography}

Yolanda F. Wiersma is an Assistant Professor of Biology at Memorial University of Newfoundland. Her research interests are in Landscape Ecology, Wildlife Ecology and Conservation Biology in the Canadian boreal region. John Sandlos is an Associate Professor of History at Memorial University of Newfoundland. His research is focused on wildlife issues and abandoned mines in northern Canada.

\section{Endnotes}

\footnotetext{
${ }^{1}$ For an overview of wildlife restoration initiatives, see David S. Maeher, Reed F. Noss and Jeffry L. Larkin, Large Mammal Restoration: Ecological and Sociological Challenges in the $21^{\text {st }}$ Century (Washington: Island Press, 2001).

${ }^{2}$ See Ernest Thompson Seton, Lives of Game Animals, An Account of those Land Animals in America North of the Mexican Border, which are considered "Game," either because they have held the Attention of Sportsmen, or received the Protection of Law, Volume 3, Part 1-2, (Boston: Charles T. Branford, Company, 1953), 655-56.

${ }^{3}$ J. Dewey Soper, "History, Range and Home Life of the Northern Bison," Ecological Monographs 2 (Oct. 1941): 362. Soper's estimate is cited in the following publications: National Wood Bison Recovery Team, National Recovery Plan for the Wood Bison (Bison bison athabascae). National Recovery Plan No. 21 (Ottawa: Environment Canada, 2001); William Harper and Cormack Gates, "Recovery of Wood Bison in British Columbia," in L.M. Darling, ed. 2000. Proceedings of a Conference on the Biology and Management of Species and Habitats at Risk, Kamloops, B.C., Volume Two B.C. Ministry of Environment, Lands and Parks, Victoria, B.C. and University College of the Cariboo, Kamloops, B.C. (15-19 Feb.,1999), 915; British Columbia Ministry of Water, Land and Air Protection, Wildlife at Risk in British Columbia - Wood Bison. http://www.env.gov.bc.ca/wld/documents/wbison.pdf (accessed Nov. 27, 2009), 1.

${ }^{4}$ Using article index Scopus, we found the following 19 papers in the peer reviewed scientific literature (dates ranging from 1936 to 2007) that cited Seton's population estimates as a credible baseline for various mammal populations. For citations of Seton's bighorn (or mountain) sheep estimates, see Helmut K. Buechner, "the Bighorn Sheep in the United States," Wildlife Monographs 4 (May 1960): 3-174; Fred Mallery Packard, “An Ecological Study of the Bighorn Sheep in Rocky Mountain National Park,
} 
Colorado," Journal of Mammalogy 27 (February 1946): 3-28; Lester J. McCann, "Ecology of the Mountain Sheep," American Midland Naturalist 56 (October 1956): 297-324; Gustavo A. Gutierrez-Espelata, Philip W. Hedrick, Steven T. Kalinowski, Daniel Garrigan, Walter M. Boyce, "Is the Decline of Desert Bighorn Sheep from Infectious Disease the Result of Low MHC Variation?" Heredity 86 (2001): 439-450; Paul R. Krausman, Peter Bangs, Kyran Kunkel, Michael K. Phillips, Zack Parsons, and Eric Rominger, "Mountain Sheep Restoration through Private/Public Partnership," Large Mammal Restoration, 231;. For references to Seton's elk estimates, see Jeffery L. Larkin, Roy A. Grimes, Louis Cornicelli, John J. Cox, and David S. Maehr, "Returning Elk to Appalachia, Foiling Murphy's Law," Large Mammal Restoration, 101; Jason F. Hicks, Janet L. Rachlow, Olin E. Rhodes, Jr., Christen L. Williams, Lisette P. Waits, "Reintroduction and Genetic Structure: Rocky Mountain Elk in Yellowstone and the Western States," Journal of Mammalogy 88 (2007): 129-38; Rick Rosatte, Joe Hamr, Jim Young, Ivan Filion, Howard Smith, "The Restoration of Elk (Cervus elaphus) in Ontario, Canada: 1998-2005," Restoration Ecology 15 (March 2007): 34-43. For references to Seton's estimates for wolves, see C. Vilà, R. Amorim, J.A. Leonard, D. Posada, J. Castroviejo, F. Petrucci-Fonsesca, K.A. Crandall, H. Ellegren, R.K. Wayne, "Mitochondrial DNA Phylogeography and Population History of the Grey Wolf Canis lupus," Molecular Ecology 8 (1999): 2089-2103; Jennifer A. Leonard, Carles Vilà, Robert K. Wayne, "Legacy Lost: Genetic Variability and Population Size of Extirpated US Grey Wolves (Canis lupus)," Molecular Ecology 14 (2005): 9-17. Seton's bison estimate has been revised downwards: see Natalie Dierschke Halbert, "The Utilization of Genetic Markers to Resolve Modern Management Issues in Historic Bison Populations: Implications for Species Conservation," (PhD Dissertation, Texas A\&M University December 2003), 3. But even with this downward revision of bison numbers, Seton's estimate is often mentioned as the upper end of a historical range of estimates. See Floyd Larson, "The Role Bison in Maintaining the Short Grass Plains," Ecology 21 (April 1940): 113-121; George Arthur, "The North American Plains Bison: A Brief History," Prairie Forum 9 (Winter 1984): 282; Frank Camp, "The Tragedy of the American Buffalo," Canadian West 6 (1990): 126; Judit L. McDonald, "Essay: Bison Restoration in the Great Plains and the Challenge of their Management," Great Plains Research 11 (Spring 2001): 104. For more isolated references to Seton's estimates of other species, see James Beer, "Distribution and Status of Pronghorn Antelope in Montana," Journal of Mammalogy 25 (February 1944): 43-46; Daniel W. Mulhern and Craig J. Knowles, "Black-Tailed Prairie Dog Status and Future Conservation Planning," Conserving Biodiversity on Native Rangelands, Symposium Proceedings, August 17, 1995, Fort Robinson State Park, Nebraska (Fort Collins, CO: U.S. Department of Agriculture, Forest Service, Rocky Mountain Forest and Range Experiment Station), 19-29; Robert J. Naiman, Jerry M. Melillo, John E. Hobbie, "Ecosystem Alteration of Boreal Forest Streams by Beaver (Castor Canadensis)," Ecology 67 (October 1986): 1254-69; Robert J. Naiman, Carol A. Johnston, James C. Kelley, "Alteration of North American Streams by Beaver," Bioscience 38 (December 1988): 753-62. Seton's populations estimates of bison, antelope, white-tailed deer, elk, and mule deer were all cited Frederic E. Clements' famous discussion of successional climax. See Clements, "Nature and Structure of the Climax," Journal of Ecology 24 (February 1936): 252-84. The authors have also encountered high numbers of references to Seton in the popular natural history literature and in government reports. For the prairie dog example see, Lance T. Vermeire, Rod K. Heitschmidt, Patricia S. Johnson, Bok F. Sowell “The Prairies Dog Story: Do we Have it Right?" BioScience 54 (July 2004): 689-95.

${ }^{5}$ Loren McClenachan, "Historical Declines of Goliath Grouper Populations in South Florida, USA" Endangered Species Research 7 (2009): 175-81. For other archival studies, see Richard B. King, Michael J. Oldham, Wayne F. Weller, Douglas Wynn. "Historic and Current Amphibian and Reptile Distributions in the Island Region of Western Lake Erie," American Midland Naturalist 138 (July 1997): 153-73. See also Mark Madison, "Conserving Conservation: Field Notes from an Animal Archive," The Public Historian 26 (Winter 2004): 145-55. For studies using land survey data, see Andrew P. Rayburn and Annabel L. Major, "Using Landscape History and Baseline Data in the Restoration of a Midwestern Savanna," Journal of the Iowa Academy of Science 115 (2008): 1-11. A summary of the use and limitations of survey data for ecological work can be found in L.A. Shulte and D. J. Mladenoff, "The Original US Public Land Survey Records: their use and Limitations in Reconstructing Presettlement Vegetation," Journal of Forestry 99 (2001): 5-10.

${ }^{6}$ For genetic analysis, see M.K. Schwartz, K.B. Aubry, K.S. McKelvey, K.L. Pilgrim, J.P. Copeland, J.R. Squires, R.M. Inman, S.M. Wisely and L.F. Ruggiero, "Inferring Geographic Isolation of Wolverines in California Using Historical DNA," Journal of Wildlife Management 71 (2007): 2170-79. For sediment cores, see Frank E. Marshall III, G. Lynn Wingard and Patrick Pitts, "A Simulation of Historic Hydrology and Salinity in Everglades National Parks: Coupling Paleoecologic Assemblage Data with Regression Models," Estuaries and Coasts 32 (2009): 37-53. For a zooarchaeological study, see Maribeth S. Murray,

"Zooarchaeology and Arctic Marine Mammal Biogeography, Conservation and Management," Ecological Applications 18 (2008): S41-S55. For tree ring data, see Lee E. Frelich and Craig G. Lorimer, "Natural Disturbance Regimes in Hemlockhardwood Forests of the Upper Great Lakes Region," Ecological Monographs 61 (1991): 145-64.

${ }^{7}$ See P. Arcese and A.R.E. Sinclair, "The Role of Protected Areas as Ecological Baselines," Journal of Wildlife Management 61 (1997): 587-602; A.R.E. Sinclair, Simon A.R. Mduma and Peter Arcese, "Protected Areas as Biodiversity Benchmarks for Human Impact: Agriculture and the Serengeti Avifauna," Proceedings of the Royal Society London, Series B. 269 (2004): 24015.

${ }^{8}$ For critiques of protected areas as baselines for ecological change, see G.E. Davis, D.M. Graber and S.A. Acker, "National Parks as Scientific Standards for the Biosphere; Or, how are you going to tell how it used to be, when there's nothing left to see?" The George Wright Forum 21 (2004): 34-44; T. Josefsson, G. Hörnberg, L. Östlund, "Long-term Human Impact and Vegetation Changes in a Boreal Forest Reserve: Implications for the use of Protected Areas as Ecological References" Ecosystems 12 (2009): 1017-36. For an explanation of historical range of variability, see Peter B. Landres, Penelope Morgan, Frederick J. Swanson, "Overview of the use of Natural Variability Concepts in Managing Ecological Systems" Ecological Applications 9 
(1999): 1179-88; Gregory H. Aplet and William S. Keeton, "Application of Historical Range of Variability Concepts to Biodiversity Conservation.” In Practical Approaches to the Conservation of Biological Diversity, Richard K. Baydack, Henry Campa, Jonathan B. Haufler, eds. (Washington: Island Press, 1999), 71-86. For a discussion of back-casting, see H. Kokko, E. Helle, J. Lindström, E. Ranta, T. Sipliä, F. Courchamp, "Backcasting Population Sizes of Ringed and Grey Seals in the Baltic and Lake Saimaa During the $20^{\text {th }}$ Century" Annales Zoologici Fennici 36 (1999): 65-73. For modeling historical habitat change see Etouko Nonaka, Thomas A. Spies, "Historical Range of Variability in Landscape Structure: a Simulation Study in Oregon, USA," Ecological Applications 15 (2005): 1727-46.

${ }^{9}$ For example see A.R. Hoelzel, J. Halley, S.J. O’Brien, C. Campagna, T. Arnborm,, B. LeBoeuf, K. Ralls, G.A. Dover, "Elephant Seal Genetic Variation and the use of Simulation Models to Investigate Historical Population Bottlenecks" The Journal of Heredity 84 (1993): 443-9; Hans J. Skuag, Lennnart Frimannslund, Nils I. Øien, "Historical Population Assessment of Barents Sea Harp Seals (Pagophilus groenlandicus)," ICES Journal of Marine Science 64 (2007): 1356-65.

${ }^{10}$ For the upland bird study, see David R. Foster, Glenn Motzkin, Debra Bernardos, James Cardoza, "Wildlife Dynamics in the Changing New England Landscape,” Journal of Biogeography 29 (2002): 1337-57. For the bison study, see Joshua J.

Millspaugh, Robert A. Gitzen, Daniel S. Licht, Sybill Amelon, Thomas W. Bonnot, David S. Jachowshi, D. Todd Jones-Farrand, Barbara J. Keller, Conor P. McGowan, M. Shane Pruett, Chadwick D. Rittenhouse, Kimberly M. Suedkamp Well, "Effects of Culling on Bison Demographics in Wind Cave National Park, South Dakota," Natural Areas Journal 28 (2008): 240-50. For a historical treatment of this issue, see Andrew Isenberg, The Destruction of the Bison (Cambridge: Cambridge University Press, 2000). 